\title{
Reproductive activities of two zooplanktivorous clupeid fish in relation to the seasonal abundance of copepod prey in the northern end of Lake Tanganyika
}

\author{
N'sibula Mulimbwa ${ }^{1, *}$, Jouko Sarvala ${ }^{2}$ \& Joost A.M. Raeymaekers ${ }^{3,4}$
}

1 CRH Uvira DR Congo, P.O. Box 73 Uvira Sud - Kivu.

2 University of Turku, Department of Biology, FI-20014 Turku, Finland.

3 University of Leuven, Laboratory of Biodiversity and Evolutionary Genomics, Ch. Deberiotstraat, 32, B-3000 Leuven, Belgium.

4 University of Basel, Zoological Institute, Vesalgasse 1, 4051 Basel, Switzerland.

* Corresponding author: N'sibula Mulimbwa, CRH Uvira DR Congo, P.O. Box 73 Uvira Sud - Kivu.

E-mail: mulimbwa49@gmail.com

\begin{abstract}
Reproductive activities of two commercially exploited clupeid fishes (Stolothrissa tanganicae and Limnothrissa miodon) in the northern end of Lake Tanganyika (Bujumbura sub-basin) were investigated during two different years (2004-2005 and 2007-2008). We hypothesized that the timing of largest reproductive investment in these pelagic species coincides with the onset of the rainy season and the highest abundance of copepod prey. For S. tanganicae, the gonadosomatic index (GSI) was significantly higher prior to the onset of the rainy season, and this was observed in both years. For L. miodon, however, this pattern was overall weaker and only statistically significant in 2004-2005. In both species, spawning activities did not seem to be adjusted to provide optimal feeding conditions for the larvae. Instead, investment in reproduction seemed to be related to the availability of copepods in the preceding months. We conclude that the timing of reproductive activities in these clupeids is species-specific, and might be subject to strong year-to-year variation.
\end{abstract}

KEY-WORDS: Clupeidae, copepod, fisheries, gonadosomatic index, reproductive activities

\section{INTRODUCTION}

Lake Tanganyika is the oldest of the East African Great Lakes (COULTER, 1991) and is the second largest and deepest freshwater body in the world. Up to now, around 1200 species have been identified in this lake, classifying it at second position in biodiversity (COHEN et al., 1993). Among the main groups, the fishes show a high degree of biodiversity (VAN STEENBERGE et al., 2011). The last whole-lake overview indicated 250 cichlid species (95\% endemics) and 75 non-cichlid species (59\% endemics) (SNOEKS, 2000).

Stolothrissa tanganicae REGAN, 1917, and Limnothrissa miodon (BOULENGER, 1906) (Phylum Chordata, Class Osteichthyes) are commercially-exploited clupeid fishes that provide a vital source of livelihood and food supply to more than 10 million people living in the surroundings of Lake Tanganyika (MöLSÄ et al., 1999). Together they represent $60 \%$ (MÖLSÄ et al., 1999) to $90 \%$ (MulimBWA, 2006) of the total pelagic commercial fish catches from Lake Tanganyika. Unfortunately, recent statistics show that the amount of catch is decreasing, at least in the northern part of the lake (MULIMBWA, 2006; LTA SECRETARIAT, 2012). Some authors have related decreases of catch to climate change (PLISNIER, 1997; O'ReILly et al. 2003), but so far overfishing is likely to be the major reason because of the excessive fishing pressure that has doubled since the mid-1990s (MulimBWA, 2006; SARVALA et al., 2006a, 2006b; VAN DER KNAAP et al., 2014). This applies particularly 
to the northern part of the lake, which has the highest fishing effort per $\mathrm{km}$ of shoreline due to high densities of lift nets and traditional fishing units (MÖLSÄ et al., 1999; VAN DER KNAAP et al., 2014).

The biology of $S$. tanganicae and L. miodon has been the subject of several studies supporting fisheries management. These investigations have documented life history (MARLIER, 1957), life cycle and length at sexual maturity (MANNINI et al., 1996), population dynamics (SHIRAKIHARA et al., 1992), reproduction and recruitment (MulimbWA \& SHIRAKIHARA, 1994), and spatio-temporal distribution (PLISNIER et al., 2009). Several studies also investigated the feeding biology of both species (POLL, 1953; CHÈNÉ, 1975; MANNINI et al., 1996; LENSU, 1998; ISUMBISHO et al., 2004), as well as the ecology and distribution of zooplankton as their most important prey category (NARITA et al., 1985; MulimbWA, 1988 and 1991; CoENEN, 1995; BWEBWA, 1996; KURKI et al., 1999; SARVALA et al., 1999; VUORINEN et al., 1999). Larvae of $S$. tanganicae have been reported to feed on phytoplankton (CHÈNÉ, 1975), but later studies suggest that their main food source is copepod nauplii (Lake Tanganyika Research Project, unpublished [1998]). Adults mainly feed on copepods, particularly Tropodiaptomus simplex (SARS, 1909) (CHÈNÉ, 1975; MGANA et al., 2014); bigger adults also take pelagic shrimps (LENSU 1998; see also COULTER, 1991). In Lake Kivu, larvae of L. miodon (10-35 mm) feed preferentially on copepods (nauplii), but also on adult cladocerans, chironomid larvae, Ephemeroptera larvae, vegetal debris, diatoms, Chlorophyceae filaments and organic rubbish (DE IONGH et al., 1983). Juveniles of L. miodon (30-70 mm) from lake Kivu feed preferentially on copepods, but also on chrysophytes, Microcystis, Rotifera, insect larvae, and nauplii (DE IONGH et al., 1983). In Lake Kivu, adults of L. miodon (85 $-110 \mathrm{~mm}$ ) feed preferentially on chironomids, juveniles of L. miodon, copepods, Microcystis, land insects, and Trichoptera (DE IONGH et al., 1983). In Lake Tanganyika, adult L. miodon also feed on larvae and juveniles of $S$. tanganicae, as well as on pelagic shrimps (COULTER, 1991; MANNINI et al., 1996; LENSU, 1998); L. miodon is hence more omnivorous than $S$. tanganicae, in part due to its long littoral phase during which it is using more varied food items.

In this study, we aim to further deepen the knowledge on the biology of these clupeid fishes by describing the timing of their reproductive activities. For $S$. tanganicae, there seems little agreement on the precise timing of reproduction. Sexually mature fish occur throughout the year (ELLIS, 1971) and individuals may spawn several times in a year (COULTER, 1961). Spawning peaks as indicated by variation in the relative number of ripe gonads were apparent in NovemberDecember and in April-July in Zambia (ELLIS, 1971), i.e. respectively in the beginning and at the end of the rainy season and well into the dry season. On the other hand, fry abundance in Zambia suggested a major annual spawning at the end of or right after the dry season, i.e. in August-December (COULTER, 1970), and length frequencies of older fish indicated a September peak (PEARCE, 1985). In Tanzania (Kigoma) there appears to be a peak in January-April (CHAPMAN \& VAN WeLL, 1978), while in the north in Burundi the main spawning is slightly later, in February-May (RoEST, 1977). The seasonal length-frequency distributions suggest usually four annual spawning peaks of varying strength in both Burundi and Uvira waters (Mölsä et al., 2002; MulimBWA et al., 2014). For L. miodon, it seems generally agreed that the main spawning takes place during the rainy season between November and May (MATTHES, 1967; Ellis, 1971; PeARCE, 1985; MulimbWA \& SHIRAKIHARA, 1994), although fry occur throughout the year, and a peak of spawning was recorded from August to October in the north end of the lake (ARO \& MANNINI, 1995).

What factors influence the timing of reproductive investment in both species? A number of studiesdemonstrated that theabundance of clupeid fishes is influenced by climatological conditions and associated limnological parameters (e.g. PLISNIER et al., 2009). It is therefore likely that 
climatological and limnological fluctuations also trigger reproductive activities. Recently, MulimBWA et al. (2014) investigated the relationship between seasonal changes in the pelagic catch of both clupeid species and the abundance of copepod prey. It was observed that peaks in the abundance of copepods from the onset of the rainy season onwards (OctoberApril) were correlated with the appearance of strong cohorts of both $S$. tanganicae and $L$. miodon. However, various strong cohorts in both species clearly did not match with peaks in the abundance of copepods. Small S. tanganicae
(2-4 months old) were observed almost year round except in February, May and NovemberDecember. The smallest $L$. miodon were around in July-September, November, and MarchApril. It therefore remains unclear whether or not $S$. tanganicae and L. miodon synchronize their reproductive investment with the onset of the rainy season and the highest abundance of copepod prey (i.e. from October-November onwards), which would be most favourable for their offspring. In addition, the reproductive effort of the clupeids might be regulated by the availability of zooplankton food for the

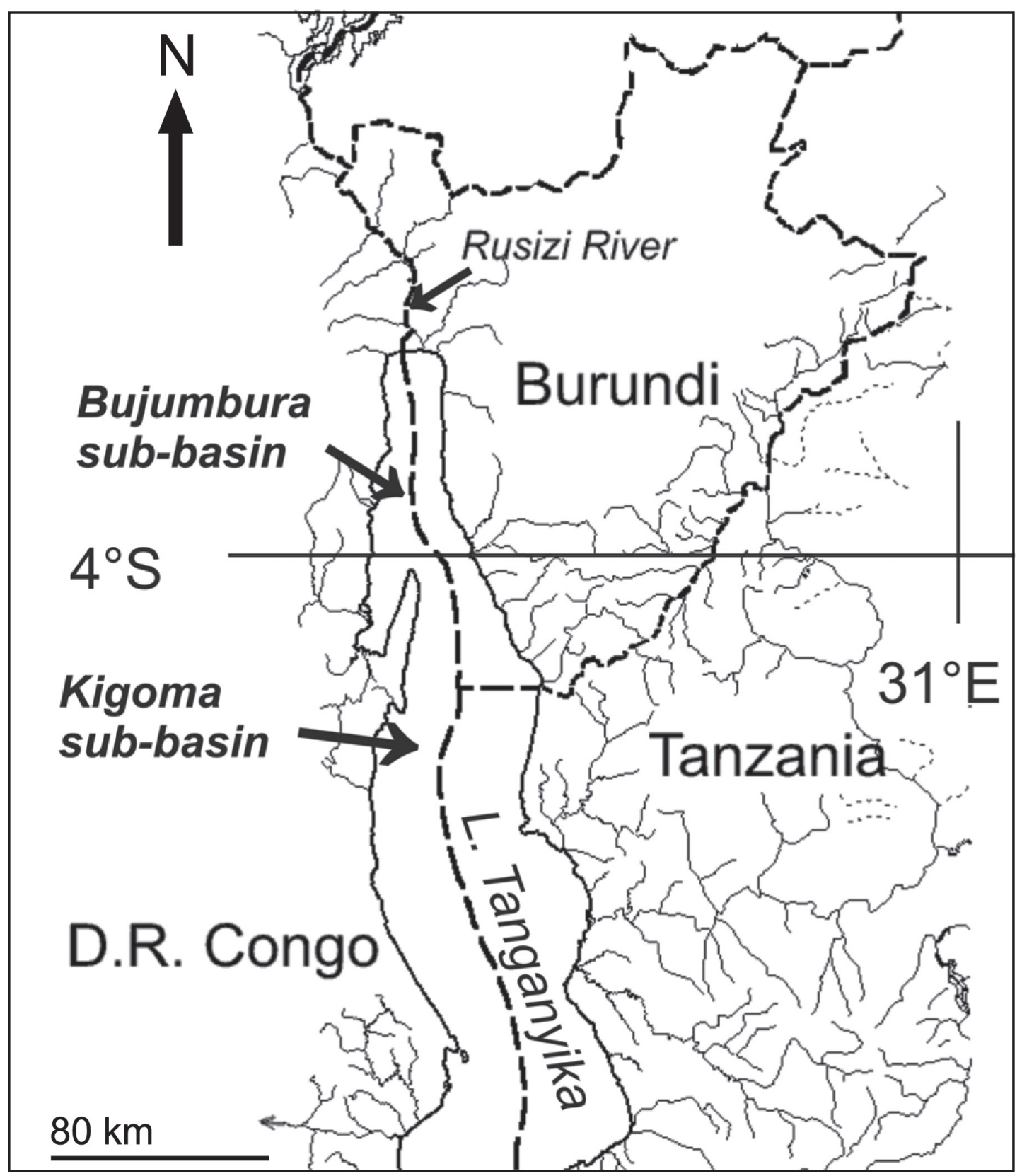

Fig. 1. - Map of the north part of Lake Tanganyika, including the Bujumbura sub-basin. 
adults before the spawning period. To test these hypotheses, we document here the reproductive activities of $S$. tanganicae and L. miodon relative to the seasonality of zooplankton in the northern end of Lake Tanganyika (Bujumbura sub-basin).

\section{MATERIAL AND METHODS}

\section{Data collection}

The study was performed in the Bujumbura subbasin at the north end of Lake Tanganyika (Fig. $1 ; 03^{\circ} 28^{\prime} \mathrm{S}$ and $29^{\circ} 17^{\prime} \mathrm{E}$ ). Fish samples were obtained from local fisheries from November 2004 to October 2005 and from March 2007 to February 2008. Rainfall data for these periods were collected at the Hydrobiological Research Center (C. R. H.) in Uvira and summed up on a monthly basis. Copepod data were obtained from February 2007 to January 2008, i.e. only for the second period.

Sampling of copepods was carried out twice a month in the pelagic area $7 \mathrm{~km}$ from the shore, as described in MuLIMBWA et al. (2014). The lake is more than $100 \mathrm{~m}$ deep here. Samples were concentrated to a volume of 40 to $60 \mathrm{ml}$, from which three $1 \mathrm{ml}$ subsamples were taken after thorough mixing. Copepods in these subsamples were identified and counted under a microscope. The copepod taxa and various developmental stages (nauplii, copepodids, males, females, and females with eggs) were identified according to AlEKSEEV (2002). Calanoid copepods were represented by only one species, Tropodiaptomus simplex. The cyclopoid copepods were grouped into small and large size classes, the small one referring to all copepodid and adult stages of Tropocyclops tenellus (SARS, 1909) and the large one to those of Mesocyclops aequatorialis KIEFER, 1929. Naupliar stages of cyclopoid copepods were counted as one group and mainly represent $M$. aequatorialis.

Fish samples were taken twice a week from artisanal lift net fishing units at the time of landing. In the artisanal fishery in the northwestern part of
Lake Tanganyika, a fishing unit is composed of two or three wooden boats of $8.0 \mathrm{~m} \mathrm{x} 1.4 \mathrm{~m}$, lift net size with $16 \mathrm{~m} \times 16 \mathrm{~m}$ mouth opening and 20 $\mathrm{m}$ depth. The mesh size of the nets is $8-10 \mathrm{~mm}$ in the upper four fifths and $6-7 \mathrm{~mm}$ in the lower one fifth. Each fishing unit uses 17 to 20 lamps and is operated by eight fishermen. With regard to $S$. tanganicae and L. miodon about a handful of fresh fish was taken as a sample from four fishing units. A minimum of $70 \mathrm{~mm}$ total length (TL) was considered, which corresponds to the minimal size at which these fishes are able to reproduce (ELLIS, 1971). In 2004-2005, 136 male S. tanganicae, 310 female S. tanganicae, 213 male L. miodon, and 243 female L. miodon were obtained. In 2007-2008, 128 male S. tanganicae, 275 female $S$. tanganicae, 192 male L. miodon, and 264 female L. miodon were included. Fish were measured and weighed, and their gonads were dissected and weighed to the nearest $0.01 \mathrm{~g}$. For 2007-2008, the gonads were inspected under a dissecting microscope and classified as mature (stage IV) or immature (stage I, II or III) according to a scale of gonad maturity based on gonad size and egg development (DE KIMPE, 1964; MiCHA, 1973). Males were considered mature when testes were white and sperm ducts were filled with sperm; females were considered mature when ovaries were light yellow to orange and oviducts were filled with ovules. Individuals that had already reproduced (stage V) were not encountered.

Between August 2009 and July 2010, additional sampling was performed by an experimental fishing unit, targeting the larvae of L. miodon, which hatch on the sand in the shallow water, close to the shoreline (MATTHES, 1967; COULTER, 1970; PEARCE, 1985). Four different beaches (Kalundu Congo SEP (mouth of Rusozi River), Kamongola, mouth of Kalimabenge River, and $\mathrm{CRH}$ Guest house) were monitored for this purpose, from $6 \mathrm{~h} 30$ to $7 \mathrm{~h} 30$ in the morning. The larvae were sampled by two persons by trawling a mosquito net (width: $2 \mathrm{~m}$; height: $1 \mathrm{~m}$ ) over a distance of $50 \mathrm{~m}$, keeping the lower part of the net close to the bottom and the upper part at the surface. A third person chased the fish larvae 


\section{TABLE 1}

Average individual biomass of three copepod species ( $\mu \mathrm{g}$ carbon) based on direct determinations with a carbon analyser (adapted from SARVALA et al., 1999).

\begin{tabular}{|lccc|}
\hline Species & $\begin{array}{c}\text { Tropodiaptomus } \\
\text { simplex }\end{array}$ & $\begin{array}{c}\text { Mesocyclops } \\
\text { aequatorialis }\end{array}$ & $\begin{array}{c}\text { Tropocyclops } \\
\text { tenellus }\end{array}$ \\
\hline Males & 2.01 & 1 & 0.16 \\
Females & 2.95 & 2.281 & 0.183 \\
Females with eggs & 3.3 & 2.315 & 0.186 \\
Copepodid & 0.717 & 0.487 & 0.132 \\
Nauplius & 0.153 & 0.098 & 0.05 \\
\hline
\end{tabular}

towards a central pocket. The total weight and the modal length of the larvae in samples were determined, and the weekly mean values across the four beaches were calculated.

\section{Data analysis}

Copepod counts were extrapolated to individuals per cubic meter, and two-week copepod abundances were calculated as the total number of copepod individuals per cubic meter. Monthly values were then calculated as the average of the two-week data. Individual carbon mass values, based on direct determinations of Tanganyika zooplankton, were derived from the literature (Table 1; SARVALA et al., 1999). Total sampled copepod biomass per month was calculated by multiplying the monthly abundance of each species and stage by the appropriate average individual mass.

Reproductive activities of the two clupeids were studied using the gonadosomatic index (GSI) of individuals larger than $70 \mathrm{~mm} \mathrm{TL}$. The GSI was defined as the percentage of gonad weight of total body weight. For 20072008 , the monthly percentage of mature gonads was calculated as an additional measure of reproductive activity.

Student's t tests were used to test the differences in rainfall, and copepod abundances and biomass between the rainy season (October to April) and the dry season (May to September). ANOVA, followed by post hoc Tukey tests, was used to test the fluctuations between months for the GSI. As the variation in GSI between months might be influenced by cohort structure and size differences, month effects on GSI were also tested with an ANCOVA including total length as a covariate. For 2007-2008, a chi-square test was used to evaluate the significance of monthto-month fluctuations in the percentage of mature gonads.

Pearson correlations and linear regressions were calculated with the program package PAST (HAMMER et al., 2001) to examine the relationships between the monthly changes in clupeid GSI and variations in zooplankton food available. To check whether clupeid reproductive effort might simply reflect the availability of food, GSI was compared with the biomass of copepod prey during the concurrent and 1-3 previous months, both separately and as averaged combinations of 2-4 months. Further, to check whether the timing of clupeid reproduction was adjusted to optimise food availability for the larval and young fish, GSI was compared with the biomass of copepod food in the following month.

\section{RESULTS}

\section{Rainfall and copepods}

Total rainfall in 2004-2005 (1335 mm) was considerably higher than in 2007-2008 (814 mm). In 2004-2005, the monthly rainfall was high from December until May, and low from June until 
October (Fig. 2A). In 2007-2008, a similar pattern with slightly different timing was observed with moderate to strong rainfall from February until May, moderate to weak rainfall from June to
September, and again moderate to strong rainfall from October until January. Similar fluctuations were observed for total copepod biomass in 2007-2008 with high values in February, April
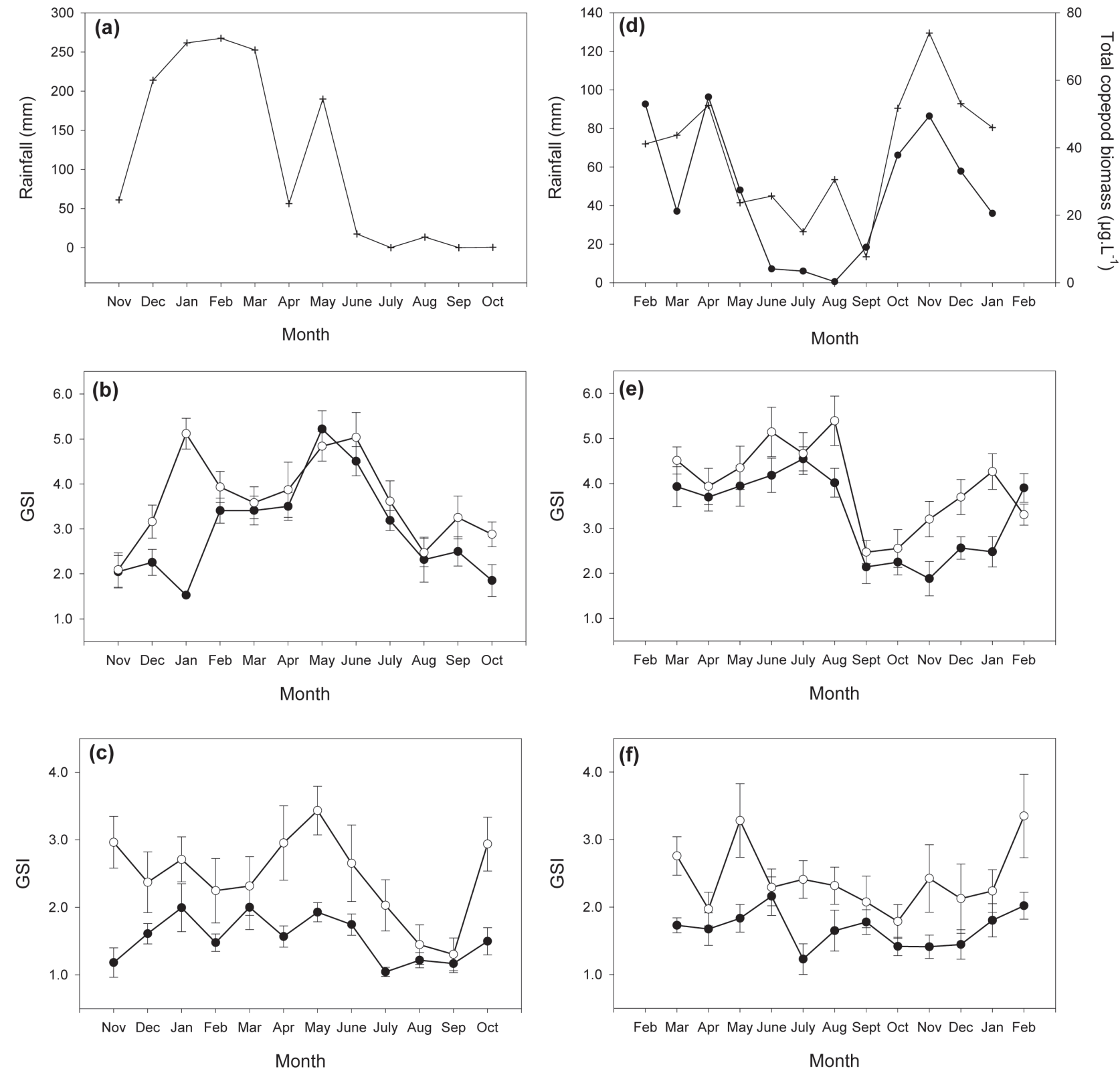

Fig. 2. - Monthly rainfall, total copepod biomass, and reproductive investment of two clupeid fishes in the northern end of Lake Tanganyika, from November 2004 until October 2005 (left) and from February 2007 until February 2008 (right). A) Average monthly rainfall (mm) in 2004-2005. B) Gonadosomatic index in males (black dots) and females (circles) of Stolothrissa tanganicae in 2004-2005. C) Gonadosomatic index in males (black dots) and females (circles) of Limnothrissa miodon in 2004-2005. D) Average monthly rainfall (left axis in $\mathrm{mm}$; cross marks) and total copepod biomass (right axis in $\mu \mathrm{g}$ carbon $\mathrm{L}^{-1}$; black dots) in 2007-2008 (data from MulimBwA et al., 2014). E) Gonadosomatic index in males (black dots) and females (circles) of Stolothrissa tanganicae in 2007-2008. F) Gonadosomatic index in males (black dots) and females (circles) of Limnothrissa miodon in 2007-2008. Vertical bars represent standard errors. 
TABLE 2

Differences between the rainy (October to April) and dry season (May to September) of 2007-2008 in rainfall and the abundances and biomasses of the main zooplankton categories and the total copepods (SE: standard error; C+A: copepodids and adults; Student's t-test assuming unequal variances; significant P-values in bold; $\mathrm{n}_{\text {rainy }}=7 ; \mathrm{n}_{\mathrm{dry}}=5$ ).

\begin{tabular}{|c|c|c|c|c|}
\hline Variable & Mean rainy season (SE) & Mean dry season (SE) & $\mathrm{t}$ & $\mathrm{P}$ \\
\hline Rainfall (mm month $\left.{ }^{-1}\right)$ & $90.5(7.2)$ & $36.0(7.1)$ & 5.39 & 0.0003 \\
\hline \multicolumn{5}{|l|}{ Copepod abundance (ind. $\mathrm{L}^{-1}$ ) } \\
\hline Tropodiaptomus simplex $\mathrm{C}+\mathrm{A}$ & $6.7(1.7)$ & $1.3(0.5)$ & 3 & 0.02 \\
\hline Mesocyclops aequatorialis $\mathrm{C}+\mathrm{A}$ & $21.3(8.3)$ & $6.2(4.1)$ & 1.62 & 0.14 \\
\hline Tropocyclops tenellus $\mathrm{C}+\mathrm{A}$ & $3.5(1.2)$ & $1.2(0.6)$ & 1.71 & 0.13 \\
\hline Copepoda nauplii & $97.9(24.7)$ & $22.1(17.7)$ & 2.49 & 0.03 \\
\hline Total Copepoda & $129.3(24.5)$ & $30.7(22.5)$ & 2.97 & 0.01 \\
\hline \multicolumn{5}{|l|}{ Copepod biomass ( $\mu$ g carbon $\mathrm{L}^{-1}$ ) } \\
\hline Tropodiaptomus simplex $\mathrm{C}+\mathrm{A}$ & $11.7(3.6)$ & $2.2(0.8)$ & 2.58 & 0.04 \\
\hline Mesocyclops aequatorialis $\mathrm{C}+\mathrm{A}$ & $16.1(4.6)$ & $4.5(2.4)$ & 2.26 & 0.05 \\
\hline Tropocyclops tenellus $\mathrm{C}+\mathrm{A}$ & $0.5(0.2)$ & $0.2(0.1)$ & 1.79 & 0.11 \\
\hline Copepoda nauplii & $9.9(2.5)$ & $2.3(1.8)$ & 2.51 & $\mathbf{0 . 0 3}$ \\
\hline Total Copepoda & $38.2(5.4)$ & $9.2(4.9)$ & 4.01 & 0.002 \\
\hline
\end{tabular}
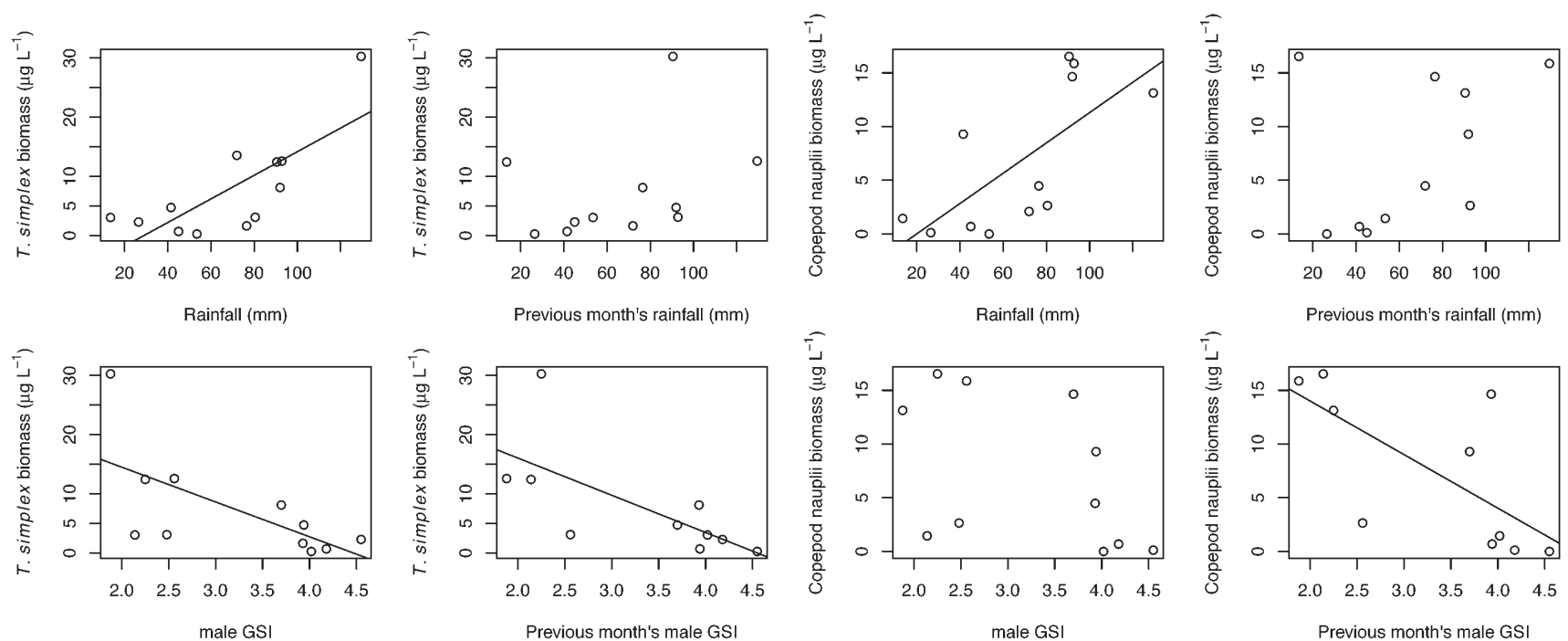

Previous month's male GSI
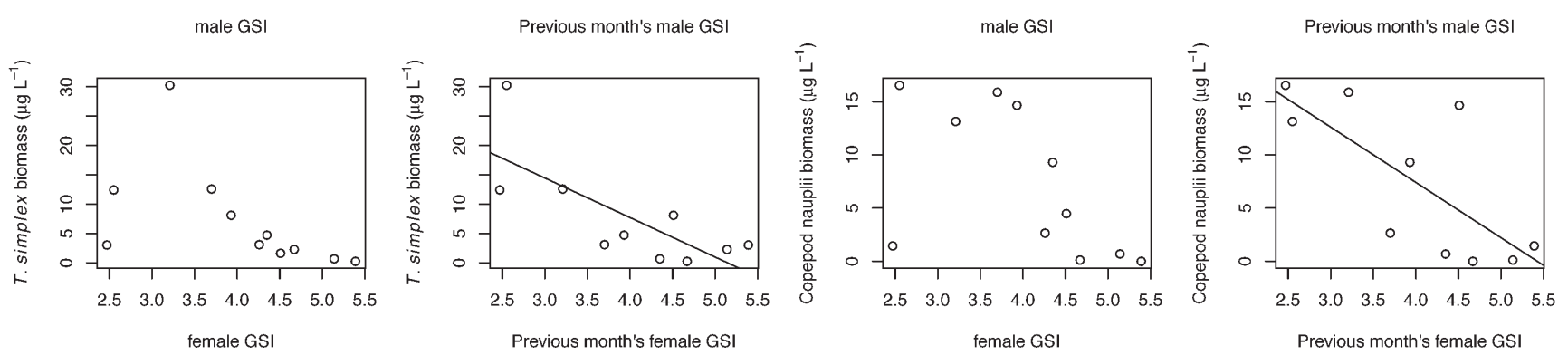

Fig. 3. - Rainfall and gonadosomatic index (GSI) in male and female Stolothrissa tanganicae in the concurrent and preceding month versus T. simplex copepodid and adult biomass and copepod nauplii biomass, from March 2007 until February 2008. Relationships marked with a regression line are significant. 


\section{TABLE 3}

Mean GSI in the rainy season (October to April) and the dry season (May to September) and ANOVA/ANCOVA between months for males (m) and females (f) of two clupeid fishes. P-values in bold indicate significant differences between months before (ANOVA) and after (ANCOVA) controlling for total length. Note that the GSI was consistently higher in the dry season than in the rainy season for S. tanganicae, but not for L. miodon. See Figure 2 for month-to-month fluctuations in GSI. SE: standard error.

\begin{tabular}{|cccccccc|}
\hline & \multicolumn{2}{c}{ Averages by season } & ANOVA between months & $\begin{array}{c}\text { ANCOVA between } \\
\text { months }\end{array}$ \\
\hline \multirow{2}{*}{ Year } & Species (sex) & $\begin{array}{c}\text { Mean rainy } \\
\text { season (SE) }\end{array}$ & $\begin{array}{c}\text { Mean dry } \\
\text { season (SE) }\end{array}$ & $\mathrm{F}$ & $\mathrm{p}$ & $\mathrm{F}$ & $\mathrm{p}$ \\
\hline $2004-2005$ & S. tanganicae (m) & $2.77(0.15)$ & $3.79(0.20)$ & $\mathrm{F}_{11,124}=8.95$ & $<\mathbf{0 . 0 0 0 1}$ & $\mathrm{F}_{11,123}=9.89$ & $<\mathbf{0 . 0 0 0 1}$ \\
& S. tanganicae (f) & $3.51(0.15)$ & $4.01(0.22)$ & $\mathrm{F}_{11,298}=6.12$ & $<\mathbf{0 . 0 0 0 1}$ & $\mathrm{F}_{11,297}=5.95$ & $<\mathbf{0 . 0 0 0 1}$ \\
& L. miodon (m) & $1.59(0.08)$ & $1.39(0.07)$ & $\mathrm{F}_{11,200}=3.58$ & $\mathbf{0 . 0 0 0 1}$ & $\mathrm{F}_{11,199}=3.63$ & $\mathbf{0 . 0 0 0 1}$ \\
& L. miodon (f) & $2.68(0.16)$ & $2.28(0.19)$ & $\mathrm{F}_{11,231}=2.45$ & $\mathbf{0 . 0 0 6 6}$ & $\mathrm{F}_{11,230}=2.44$ & $\mathbf{0 . 0 0 6 7}$ \\
\hline $2007-2008$ & S. tanganicae (m) & $2.91(0.15)$ & $3.83(0.20)$ & $\mathrm{F}_{11,112}=6.36$ & $<\mathbf{0 . 0 0 0 1}$ & $\mathrm{F}_{11,111}=7.15$ & $<\mathbf{0 . 0 0 0 1}$ \\
& S. tanganicae (f) & $3.65(0.14)$ & $4.26(0.23)$ & $\mathrm{F}_{11,263}=5.65$ & $<\mathbf{0 . 0 0 0 1}$ & $\mathrm{F}_{11,260}=4.59$ & $<\mathbf{0 . 0 0 0 1}$ \\
& L. miodon (m) & $1.64(0.07)$ & $1.79(0.11)$ & $\mathrm{F}_{11,180}=1.25$ & 0.2552 & $\mathrm{~F}_{11,177}=0.99$ & 0.4607 \\
& L. miodon (f) & $2.36(0.14)$ & $2.34(0.14)$ & $\mathrm{F}_{11,252}=1.38$ & 0.1838 & $\mathrm{~F}_{11,251}=1.55$ & 0.1149 \\
\hline
\end{tabular}

S. tanganicae $(\mathrm{m})$

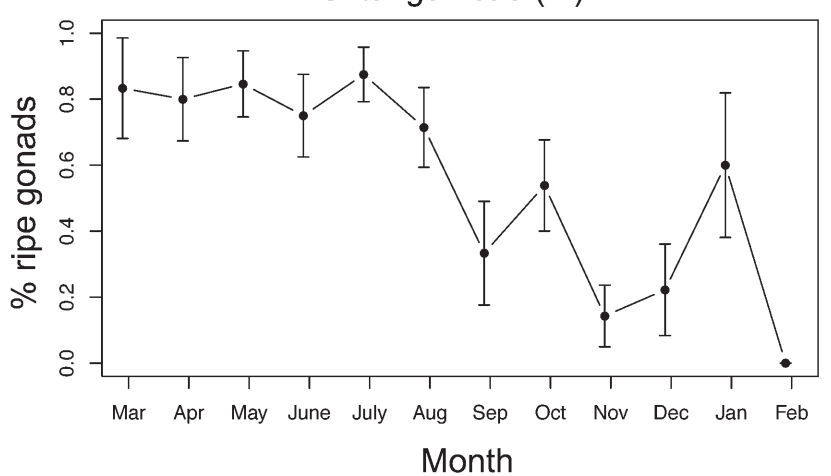

L. miodon $(\mathrm{m})$

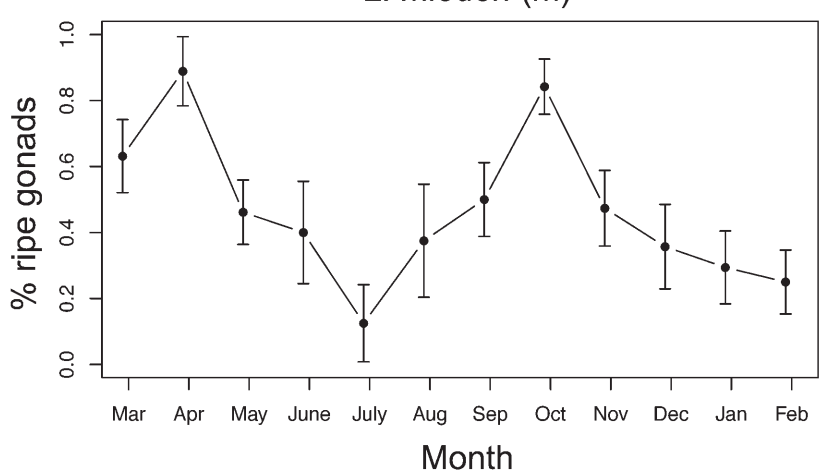

S. tanganicae (f)

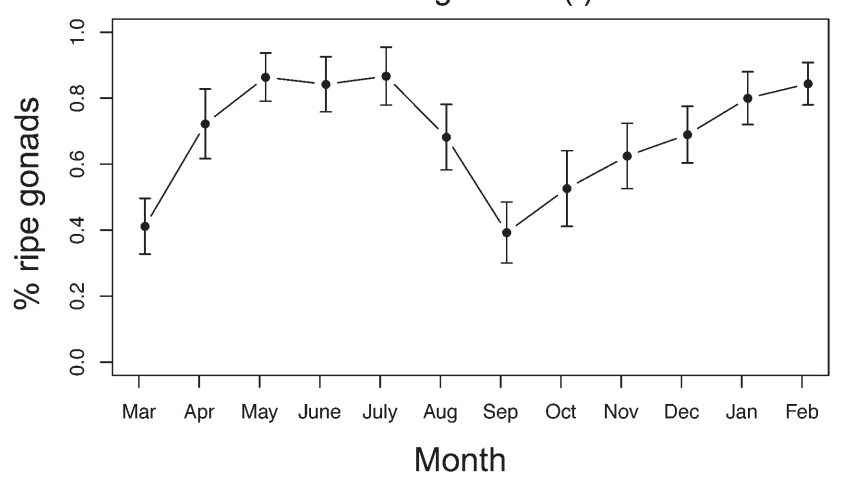

L. miodon (f)

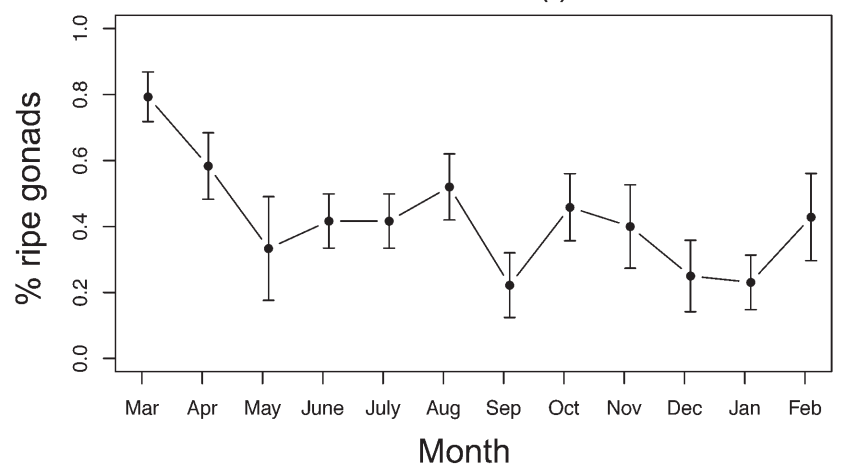

Fig. 4. - Percentage of individuals with mature gonads in males (m) and females (f) of Stolothrissa tanganicae and Limnothrissa miodon, from March 2007 until February 2008. Vertical bars represent standard errors. 
and November, and low values from June until September (Fig. 2D). Differences between the rainy and dry seasons were statistically significant for rainfall, M. aequatorialis copepodid and adult biomass, and the abundance and biomass of $T$. simplex copepodids and adults, copepod nauplii and total copepods (Table 2). Accordingly, copepod biomass was positively correlated with the rainfall of the current month (rainfall vs. $T$. simplex copepodid and adult biomass: $\mathrm{r}=0.76$, $\mathrm{p}=0.0039, \mathrm{df}=10$, Fig. 3 ; rainfall vs. copepod nauplii biomass: $\mathrm{r}=0.70, \mathrm{p}=0.0118, \mathrm{df}=10$, Fig. 3; rainfall vs. total copepod biomass: $r=$ $0.74, p=0.0060, d f=10)$. In contrast, none of the copepod biomass categories was significantly correlated with the previous month's rainfall (Fig. 3).

\section{Clupeid reproductive investment}

Stolothrissa tanganicae-Males ranged between $72 \mathrm{~mm}$ and $103 \mathrm{~mm}$ TL (average: $87 \mathrm{~mm}$ ), while females were 71-110 mm TL (average: $90.8 \mathrm{~mm}$ ). In 2004-2005, male GSI fluctuated significantly between months, with high values in May and June and low values from November to January and August to October (Fig. 2B; Table 3). In 2007-2008, a broader peak was observed from March to August, with a significant drop towards September (Fig. 2E; Table 3). Female GSI also fluctuated significantly between months (Figs 2B, E, Table 3). In 2004-2005, values were generally high from January to July, with a peak in January and a second peak from May to June (Fig. 2B). In 2007-2008, female GSI was high from March to August with a steep drop to low values in September-October; a new peak was evident in January (Fig. 2E). In both sexes and both years, the differences in GSI between months remained significant when GSI was controlled for total length (ANCOVA; Table 3), indicating that GSI fluctuations between months were not or not exclusively due to shifts in cohort structure, but to differential reproductive investment. GSI was also consistently higher in the dry season than
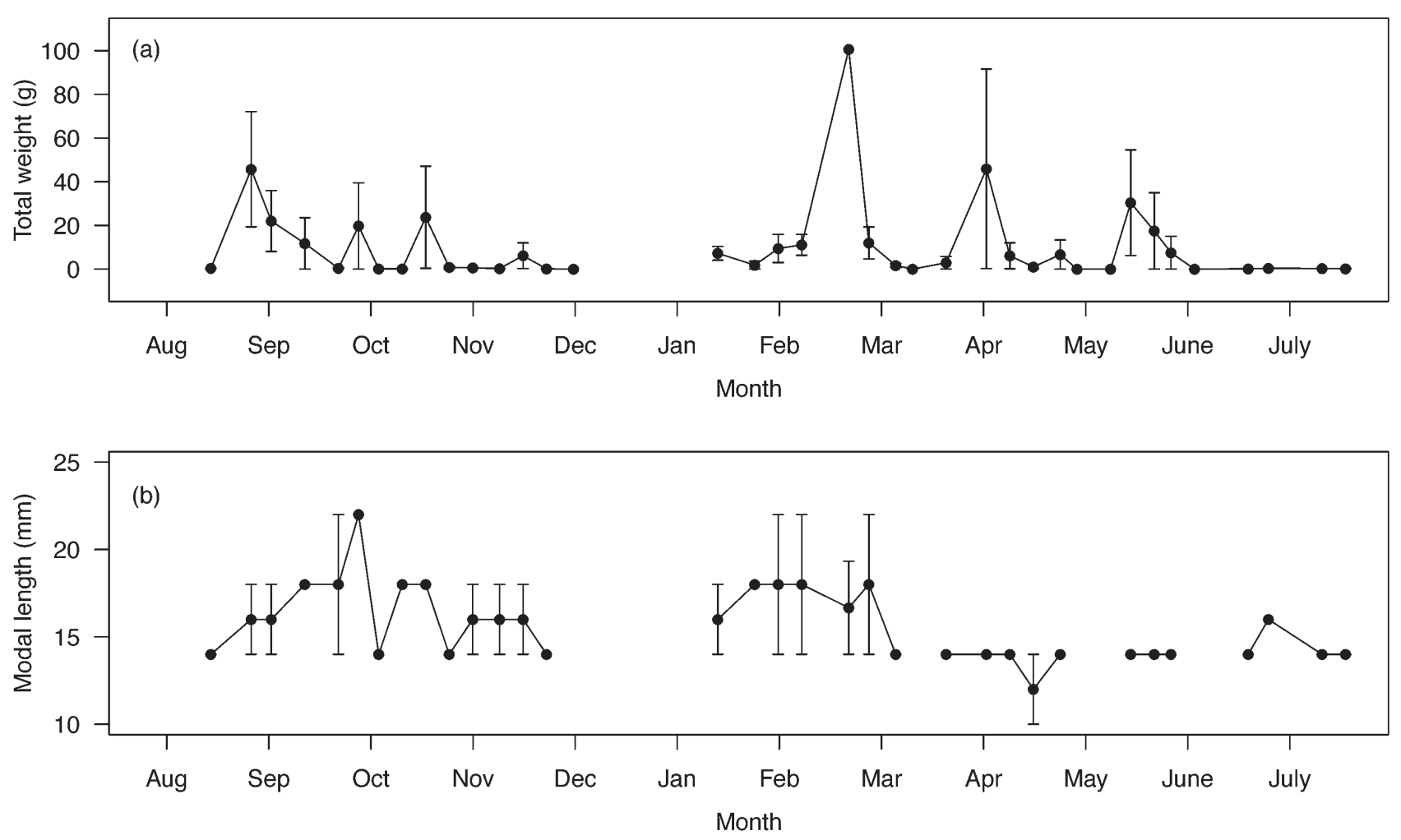

Fig. 5. - Seasonal changes in the weight (g) of the total catch and the modal length ( $\mathrm{mm}$ ) of Limnothrissa miodon larvae in the littoral samples between August 2009 and July 2010. Values represent the average of the captures at four different beaches. Vertical bars represent standard errors. 


\section{TABLE 4}

Pearson correlations of clupeid GSI with the rainfall of the corresponding and the preceding month (combined data for 2004-2005 and 2007-2008). Stan $=$ S. tanganicae, Lmio = L. miodon.

\begin{tabular}{|lccccc|}
\hline & Stan male & Stan female & Lmio male & Lmio female & df \\
\hline Rainfall, same month & -0.061 & 0.167 & 0.408 & 0.198 & 21 \\
Rainfall, preceding month & 0.119 & 0.306 & 0.375 & 0.222 & 22 \\
\hline
\end{tabular}

in the rainy season (Table 3). In 2007-2008, the percentage of males and females with mature gonads steeply decreased towards the end of the dry season, suggesting a major spawning peak in August-September (Fig. 4). These fluctuations were significant (males: $\chi^{2}=43.2, \mathrm{p}<0.0001$, $\mathrm{df}=11$; females: $\chi^{2}=37.6, \mathrm{p}<0.0001, \mathrm{df}=11$ ).
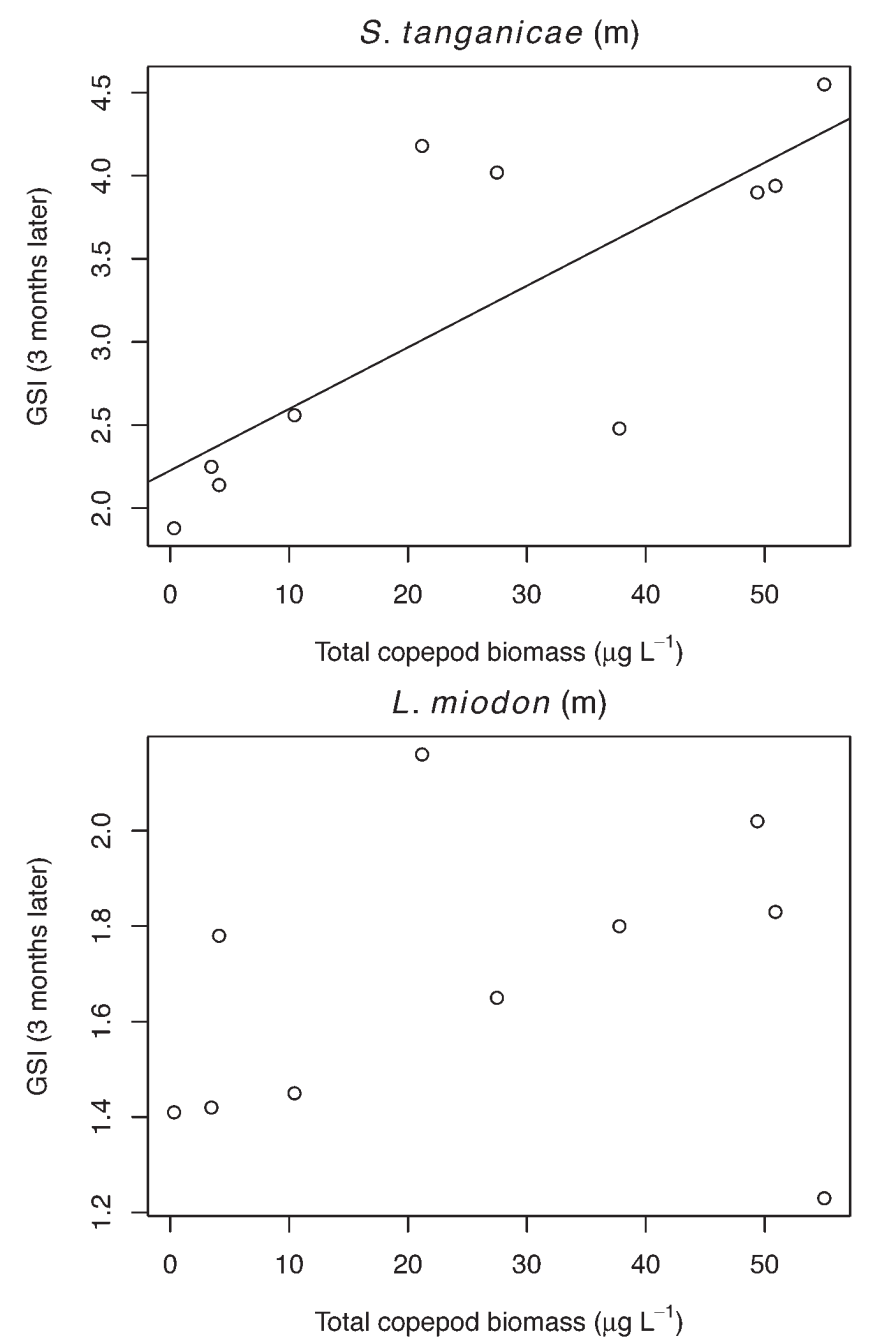

Limnothrissa miodon - Males ranged between $74 \mathrm{~mm}$ and $129 \mathrm{~mm}$ TL (average: $94.5 \mathrm{~mm}$ ), while females were $75-136.4 \mathrm{~mm}$ TL (average: $100.8 \mathrm{~mm}$ ). In 2004-2005, male GSI was high from January to June, and dropped significantly in July (Fig. 2C, Table 3). Female GSI showed a significant peak in November, May and October, and the lowest values in August-September
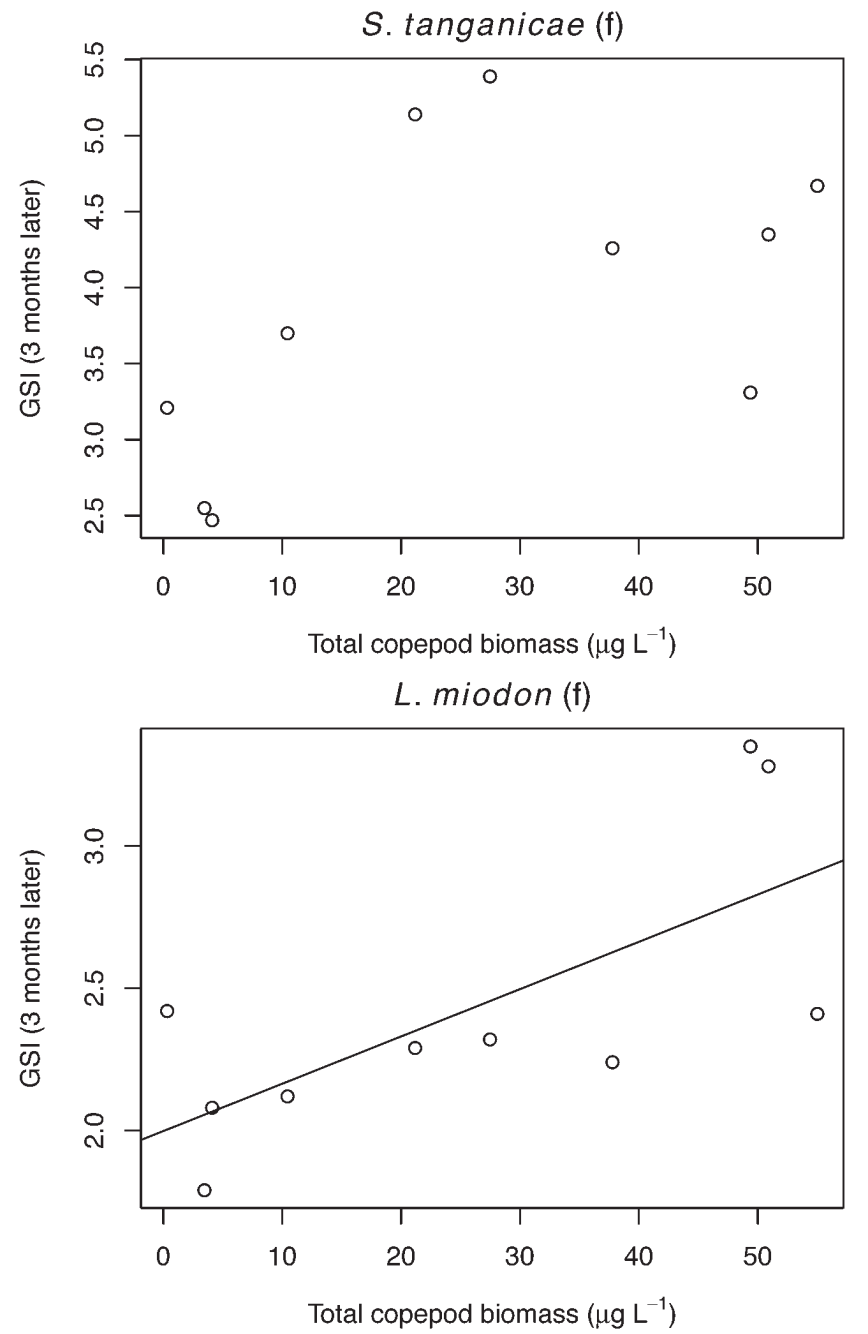

Fig. 6. - Total copepod biomass versus the average monthly gonadosomatic index (GSI) three months later in two clupeid fishes, from March 2007 until February 2008. Relationships marked with a regression line are significant. 
(Fig. 2C, Table 3). In 2007-2008, male GSI showed a subtle peak in June, while for females reproductive activity peaked in March, May and February (Fig. 2F). However, none of the differences in 2007-2008 were statistically significant. None of these results changed when GSI was controlled for total length (ANCOVA; Table 3). In contrast to $S$. tanganicae, there was no consistent difference in GSI between the rainy season and the dry season across years and sexes (Table 3). In 2007-2008, the percentage of males with mature gonads peaked in April and October, while the highest percentage of females with mature gonads was observed in March (Fig. 4). These fluctuations were significant (males: $\chi^{2}$ $=29.9, \mathrm{p}=0.0016, \mathrm{df}=11$; females: $\chi^{2}=28.45$, $\mathrm{p}=0.0028, \mathrm{df}=11)$.

Weekly captures by an experimental fishing unit at four different beaches revealed that $L$. miodon larvae predominated in the rainy season (January to May), but were also abundant at the end of the dry season (August to September) (Fig. 5). The modal length of the larvae was, most of the time, less than $19 \mathrm{~mm}$, suggesting that they were less than 1 month old (deduced from length growth curves in MuLimBwA et al., 2014).

\section{Reproductive investment vs. rainfall and copepods}

GSI versus rainfall - Clupeid GSI did not show significant correlation with the rainfall of the concurrent or the previous month (combined data for the years 2004-2005 and 2007-2008; Table 4).

GSI versus copepods in the corresponding and following month - In both clupeids, the monthly GSI showed no relationship with copepod biomass of the corresponding month (total copepod biomass or that of the separate zooplankton groups), except for a significant negative correlation between male $S$. tanganicae GSI and T. simplex copepodid and adult biomass $(\mathrm{r}=-0.649, \mathrm{p}<0.05, \mathrm{df}=9$, Fig. 3), and between female $S$. tanganicae GSI and T. tenellus $(\mathrm{r}=-$
0.723, $\mathrm{p}<0.05, \mathrm{df}=9$ ). In a similar vein, $S$. tanganicae GSI showed significant negative correlations with copepod biomass of the following month (male $S$. tanganicae vs. T. simplex copepodids and adults, and copepod nauplii: $\mathrm{r}=-0.687, \mathrm{p}<0.05$, Fig. 3; $\mathrm{r}=-0.696$, $\mathrm{p}<0.05$, Fig. 3, respectively, $\mathrm{df}=8$; female $S$. tanganicae vs. T. simplex copepodids and adults, copepod nauplii and total copepods: $r=-0.750$, p $\sim 0.05$, Fig. $3 ; r=-0.739, p<0.05$, Fig. 3 ; $r=-$ $0.633, \mathrm{p}<0.05$; respectively, $\mathrm{df}=8$ ).

\section{GSI versus copepods of previous months} - Reproductive investment in $S$. tanganicae was correlated with the food availability in the preceding months, as shown by significant correlations between average monthly GSI and copepod biomass three months earlier (male $S$. tanganicae vs. M. aequatorialis copepodids and adults: $\mathrm{r}=0.771, \mathrm{p}<0.01 \mathrm{df}=8$; male $S$. tanganicae vs. total copepops: $\mathrm{r}=0.779, \mathrm{p}<0.01 \mathrm{df}=8$, Fig. 6; female $S$. tanganicae vs. M. aequatorialis copepodids and adults: $\mathrm{r}=0.630, \mathrm{p} \sim 0.05, \mathrm{df}=8$ ). At this time lag, the GSI of female L. miodon also showed positive correlations with the biomass of $T$. simplex copepodids and adults $(\mathrm{r}=0.800$, $\mathrm{p}<0.01, \mathrm{df}=8$ ) as well as total copepods ( $\mathrm{r}=0.702$, $\mathrm{p}<0.05$, df=8; Fig. 6). At other time lags and for the total copepod biomass integrated over preceding months, no significant correlations were observed (statistics not shown).

\section{DISCUSSION}

We investigated the timing of reproductive activities of two clupeid fishes ( $S$. tanganicae and L. miodon) from the northern end of Lake Tanganyika (Bujumbura sub-basin) by comparing month-to-month fluctuations of the gonadosomatic index (GSI) with fluctuations in rainfall and the abundance of copepods. As copepods represent the main food source of larvae and juveniles of both species, but particularly $S$. tanganicae (MANNINI et al., 1996; LENSU, 1998; SARVALA et al., 2002; ISUMBISHO et al., 2004), it was expected that the main period of reproductive activity (as indicated by a significant drop in GSI 
and in the percentage of ripe gonads) would precede or coincide with the rainy season, when the availability of copepods as a food source for larvae or juveniles is maximal (CHÈNÉ, 1975; DE IOngh et al., 1983; Mgana et al., 2014). We could confirm this expectation for $S$. tanganicae in two different years (2004-2005 and 20072008), but only in one year for L. miodon (20042005). However, we found no indications that the fishes actively synchronize their reproductive activities with this optimal period (see below). Instead, correlations between GSI and copepod abundance suggested that reproductive activities are related to the availability of copepods in the preceding months.

\section{Rainfall and copepods}

Seasonal development of copepod biomass in 2007-2008 was closely associated with the rainfall pattern, at least partly because the rainfall brings new nutrients into the lake, facilitating phytoplankton production (see discussion in MulimBWA et al., 2014). In particular, the increasing food supply in early wet season is likely to have a profound effect on copepod abundance (NARITA et al., 1985; MulimBWA, 1988, 1991; KURKI, et al., 1999). Overall, phytoplankton and zooplankton are assumed to be well correlated in Lake Tanganyika (COULTER, 1991). The realized zooplankton abundance, however, results from a balance between zooplankton production and its consumption by fish and invertebrate predators. For example, the low total copepod biomass noticed in dry seasons suggests a severe predation by $S$. tanganicae showing peak catches in July (Roest, 1992; Mulimbwa, 2006; Mulimbwa et al., 2014). The dominant factor causing the high total copepod biomasses in the rainy season was likely to be the availability of phytoplankton combined with a moderate predation pressure. Comparisons of the monthly changes in copepod abundance with historical studies are difficult due to different methodologies used (RUFLI \& CHAPMAN 1976; Burgis, 1984), but the Lake Tanganyika Research (LTR) time series from the 1990s (KURKI, 1997) and the early 2000s
(MÖLSÄ et al., 2002) were based on compatible methods. In 1993-1996 and in 1999-2001, the seasonal changes in copepod biomass in the Bujumbura, Uvira and Kigoma sub-basins were highly variable with no consistent pattern relative to the dry and wet seasons (KURKI et al., 1999; MÖLSÄ et al., 2002; SARVALA et al., unpublished). The seasonality of copepods as a food source for the pelagic planktivorous fish thus varies considerably from year to year and between areas.

\section{Clupeid reproductive investment}

One of the investigated clupeid species, $S$. tanganicae, showed the highest mean values of the gonadosomatic index (GSI) in the dry season. An abrupt decline indicated that the main spawning took place a few weeks before the rainy season. Although the onset of the rainy season is accompanied by a steep increase in total copepod biomass, we have no indications that $S$. tanganicae adjusts its spawning strategy to optimize the survival of its offspring. First, it is unclear what kind of trigger the fish would use to do so. Rainfall and associated increased turbidity would be one potential trigger, but the main spawning clearly occurred before the first rains. Second, at the time of spawning food availability was still low, and hence not beneficial to the larvae that would hatch in 2-3 days (MATTHES, 1967) and likely start feeding within a week. Arguably, the timing of spawning could still be beneficial in a later developmental stage, but the benefit for the larvae as the most vulnerable stage would be larger. In the mid-1990s, MANNINI et al. (1996) observed peak values for GSI at intervals of 3-4 months in female $S$. tanganicae in the north part of Lake Tanganyika. A similar periodicity in female $S$. tanganicae was observed in this study, although for both 2004-2005 and 2007-2008 the intervals seemed to approach five months. Length-frequency distributions for 2007-2008, however, clearly indicated four annual cohorts (Mulimbwa et al., 2014), but not all of those were equally strong, and it may be difficult to 
observe any significant changes in GSI related to the weaker cohorts.

In contrast to $S$. tanganicae, and especially in 2007-2008, the reproductive activity of $L$. miodon did not suggest a main spawning event, consistent with observations in the mid-1990s by MANNINI et al. (1996). It hence seems that L. miodon is spreading its reproductive activities over longer periods of time. The reason for the variation between years remains unclear; the year 2007-2008 had lower rainfall than 2004-2005 (see Fig. 2A vs. 2D), but there were no significant differences in reproductive investment (results not shown). Repeated spawning of clupeids is an adaptation to an unstable aquatic ecosystem where considerable variation in fishing and natural mortalities causes some of the eggs to die (COUlTER, 1961). The prolonged spawning provides stable replacement by successive cohorts. However, this is only possible when there is a long period of adequate food supply for the larvae. L. miodon might obtain such supply in the littoral zone, where food is abundant yearround (COULTER, 1991).

\section{Reproductive investment vs rainfall and copepods}

The year-to-year and spatial variation in the seasonality of copepods in Lake Tanganyika is expected to lead to corresponding variability in fish reproduction. In this study, the dependence of reproductive activities of both clupeids on the copepod food source was suggested by a positive correlation between GSI and the amount of copepods available three months before. Reproductive effort in both clupeids might therefore simply reflect the amount of available food in previous months. Conversely, but only for $S$. tanganicae, we observed a negative correlation between GSI and copepod abundance in the corresponding and following month. This suggests a predation effect by emerging $S$. tanganicae cohorts on the copepods. Although rainfall was also correlated with copepod abundance, this positive relationship was only observed in the concurrent month, consistent with the short generation times of planktonic copepods. In contrast, the negative effect of predation by $S$. tanganicae lasts longer as the fish are more long-lived and the total food consumption of a fish cohort likely peaks during the first few months of life (MANNINI et al., 1996).

Changes in fishing pressure, climate change (including changes in rainfall, temperature and wind), or changes in environmental conditions in the drainage area (e.g. deforestation) might all lead to changes in the predator-prey dynamics between clupeids and copepods. Among these possible effects, changes in fishing pressure are relatively well documented (see Introduction). Overfishing in recent years might have decreased the effect of predation on copepods, such that correlations with rainfall and copepods should become predominant. This might explain why in the present situation of depleted fish stocks (e.g. Mulimbwa, 2006) we observed a clear correlation between rainfall and copepods, whereas this was not the case in the past (KURKI et al., 1999; MöLSÄ et al., 2002; SARVALA et al., unpublished) when the fish stocks were stronger and thus predation effects were much larger. Nevertheless, predation effects could still be observed even in our data.

\section{CONCLUSIONS}

Copepod zooplankton abundance was very high in the rainy season, providing an opportunity for larval clupeids to maximize survival rate. However, clupeid spawning activities did not seem to be adjusted to allow the larvae to optimally benefit from this food source. While $S$. tanganicae seemed to concentrate its reproductive activities at the end of the dry season, there was no well-defined spawning season in L. miodon. However, in both species the investment in reproduction seemed to depend on the availability of copepods three months earlier. We conclude that apart from some common elements, clupeid species may 
significantly differ in reproductive strategies. Further investigation should highlight the variation in clupeid reproductive activities across species and years, as well as the relationship with the abundance of zooplankton.

The observed differences between clupeid species are important from a management perspective.Along period of adequate food supply may be very important to support reproductive activities in species such as L. miodon, in order to maintain its intense exploitation at a sustainable level. This requires that the environmental conditions of the lake and its adjacent regions be preserved. As a littoral spawner (MATTHES, 1967; PEARCE, 1985; COULTER, 1970), L. miodon is particularly vulnerable to silting caused by soil erosion in the drainage area. Although the pelagically-spawning $S$. tanganicae is less susceptible to such changes, increased turbidity during its peak reproductive activities in the rainy season might be harmful. Thus even this species may benefit from reforestation that would help to preserve and restore the natural equilibrium of the lake, promoting the survival and growth of its copepod prey.

\section{ACKNOWLEDGEMENTS}

We thank the scientific staff of the Center of Hydrobiological Research (C.R.H) for field support. Research was sponsored by Belgian Technical Cooperation to N'sibula Mulimbwa, by University of Turku to Jouko Sarvala and by the Research Foundation - Flanders (FWO grant project G.0553.10) and a EU Marie Curie fellowship (IEF 300256) to Joost Raeymaekers.

\section{REFERENCES}

AleKSEEV VR (2002). A guide to tropical freshwater zooplankton. Backhuys Publishers, Leiden, The Netherlands.

ARo E \& MANNINI P (1995). Résultats des études de la biologie des populations des poissons sur le lac Tanganyika pendant la période de Juillet 1993 - Juin 1994. FAO/FINNIDA Recherche pour l'aménagement des Pêches au Lac Tanganyika. GCP/RAF/271/FIN-TD/38 (Fr):115 pp.

BURGIS MJ (1984). An estimate of zooplankton biomass for Lake Tanganyika. Verhandlungen Internationale Vereinigung für theoretische und angewandte Limnologie 22:1199-1203.

BWEBWA D (1996). Variations saisonnière et spatiale dans l'abondance de la communauté pelagique du zooplancton dans l'extrémité nord du Lac Tanganyika. FAO/FINNIDA Recherche pour l'aménagement des Pêches au Lac Tanganyika. GCP/RAF/271/FIN-TD/50 (Fr):17 pp.

CHAPMAN DW \& VAN Well P (1978). Growth and mortality of Stolothrissa tanganicae. Transactions of the American Fisheries Society 107:26-35.

CHÈNÉ G (1975). Etude des problèmes relatifs aux fluctuations piscicoles du Lac Tanganyika. Mémoire de licence, Université de Liège, Belgium, 108 pp.

CoENEN EJ (1995). Historical Data Report on the Fisheries Statistics, Limnology, Bromatology, Zooplankton, Fish Biology and Scientific Publications Review of Lake Tanganyika (Zaïre). FAO/FINNIDA Research for the Management of the Fisheries on Lake Tanganyika. GCP/RAF/271/ FIN-TD/31 (En \& Fr):173 pp.

COHEN AS, Bills R, C.Z. Coceuyt CZ \& CALJON AG (1993). Impact of sediment pollution on biodiversity in Lake Tanganyika. Conservation Biology 7:667-677.

COULTER GW (1961). Lake Tanganyika Research. Annual Report, Joint Fisheries Research Organisation, Zambia, 10:7-30.

COUlter GW (1970). Population changes within a group of fish species in Lake Tanganyika following their exploitation. Journal of Fish Biology 2:329-353.

COULTER GW (1991). Lake Tanganyika and its life. Natural History Museum \& Oxford University Press. London. 354 pp.

DE IONGH HH, SPLIETHOFF PC \& FRANK VG (1983). Feeding habits of the clupeid Limnothrissa miodon (Boulenger), in Lake Kivu. Hydrobiologia 102:113-122.

DE KIMPE P (1964). Contribution à l'étude hydrobiologique du Luapula-Moero. Annales du Musée Royal d'Afrique Centrale 8:128-238.

ELLIS CMA (1971). The size at maturity and breeding seasons of sardine in the southern 
Lake Tanganyika. African Journal of Tropical Hydrobiology and Fisheries 1:59-66.

HAMMER Ø, HARPER DAT \& RYAN PD (2001). PAST:Paleontological Statistics Software Package for Education and Data Analysis. Palaeontologia Electronica 4:9 pp.

ISUMBISHO M, KANINGINI M, DESCY JP \& BARAS E (2004). Seasonal and diel variations in diet of the young stages of the Limnothrissa miodon in Lake Kivu, Eastern Africa. Journal of Tropical Ecology 20:1-11.

KURKI H (1997). Résultats de l'échantillonnage de zooplancton sur trois localités lac Tanganyika:Juillet 1993 - Décembre 1995. FAO/ FINNIDA Recherche pour 1' aménagement des Pêches au Lac Tanganyika. GCP/RAF/271/FIN$\mathrm{TD} / 51$ (Fr):52 pp.

Kurki H, Vuorinen I, Bosma E \& Bwebwa D (1999). Spatial and temporal changes in copepod zooplankton communities of Lake Tanganyika. Hydrobiologia 407:105-114.

LENSU ST (1998). Stolothrissa tanganicae- ja Limnothrissa miodon -kalojen ravinnonvalinta Tanganyika-järvellä. (Diets of the clupeid fishes Stolothrissa tanganicae and Limnothrissa miodon in Lake Tanganyika.) M.Sc. thesis, Department of Applied Zoology and Veterinary Medicine, University of Kuopio, Finland. 70 pp.

LTA SECRETARIAT (2012). Report on Regional Lakewide Fisheries Frame Survey on Lake Tanganyika 2011. LTA/TECH DOC/2012/01. Bujumbura, Burundi.

MANNINI P, ARO E, KATONDA I, KISSAKA B, Mambona C, Milindi E, Paffen P \& Verburg P (1996). Pelagic fish stocks of Lake Tanganyika:biology and exploitation. FAO/ FINNIDA Research for the Management of the Fisheries on Lake Tanganyika. GCP/RAF/271/ FIN-TD/53 (En):60 pp.

MARLIER G (1957). Le Ndagala, poisson pélagique du Lac Tanganyika. Bulletin Agricole du Congo Belge. 48:409-422.

MATTHeS H (1967). Preliminary investigations into the biology of the Lake Tanganyika Clupeidae. Fisheries Research Bulletin of Zambia 4:39-45.

Mgana HF, Herzig A. \& Mgaya YD (2014). Diel vertical distribution and life history characteristics of Tropodiaptomus simplex and its importance in the diet of Stolothrissa tanganicae, Kigoma, Tanzania, Aquatic Ecosystem Health \& Management 17:14-24.
MiCHA JC (1973). Etude des populations piscicoles de l'Oubangui et tentatives de sélection et d'adaptation de quelques espèces à l'étang de pisciculture. CTFT. Paris. $110 \mathrm{pp}$.

Mölsä H, Reynolds JE, COENEN E \& LindQVist OV (1999). Fisheries research towards resource management on Lake Tanganyika. Hydrobiologia 407:1-24.

Mölsä H, Sarvala J, Badende S, Chitamwebwa D, Kanyaru R, Mulimbwa N \& Mwape L (2002). Ecosystem monitoring in the development of sustainable fisheries in Lake Tanganyika. Aquatic Ecosystem Health \& Management 5:267-281.

Mulimbwa N (1988). Seasonal changes in the abundance of zooplankters in the northwestern end of Lake Tanganyika during 1987. In:KAWANABE $\mathrm{H}$ \& KWETUENDA MK (eds) Ecological and Limnological Study on Lake Tanganyika and its Adjacent Regions V. Department of Zoology, Faculty of Science, Kyoto University, Kyoto, Japan:5:57-60.

Mulimbwa N (1991). Seasonal changes in the abundance of zooplankters in the northwestern end of Lake Tanganyika. In:KAWANABE $\mathrm{H}$ \& NAGOSHI M (eds) Ecological and Limnological Study on Lake Tanganyika and its Adjacent Regions VII. Department of Zoology, Faculty of Sciences, Kyoto University, Kyoto, Japan:96-97.

Mulimbwa N (2006). Assessment of the commercial artisanal fishing impact on three endemic pelagic fish stocks Stolothrissa tanganicae, Limnothrissa miodon and Lates stappersi in Bujumbura and Kigoma sub-basins of Lake Tanganyika. Verhandlungen Internationale Vereinigung für theoretische und angewandte Limnologie 29:1189-1193.

MULIMBWA N \& SHIRAKIHARA K (1994). Growth, recruitment and reproduction of sardines (Stolothrissa tanganicae and Limnothrissa miodon) in northwestern Lake Tanganyika. Tropics 4:57-67.

Mulimbwa N, RAEYMAeKers JAM \& SARVALA $J$ (2014). Seasonal changes in the pelagic catch of two clupeid zooplanktivores in relation to the abundance of copepod zooplankton in the northern end of Lake Tanganyika. Aquatic Ecosystem Health \& Management 17:25-33.

NARita T, Mulimbwa N \& Mizuno T (1985). Vertical distribution and seasonal abundance of zooplankters in Lake Tanganyika. African Study Monographs 6:1-16. 
O’Reilly CM, Alin SR, Plisnier P-D, COHEN AS \& MCKeE BA (2003). Climate change decreases aquatic ecosystem productivity of Lake Tanganyika, Africa. Nature 424:766-768.

PEARCEMJ(1985). Adescription and stock assessment of the pelagic fishery in the south-east arm of the Zambian waters of Lake Tanganyika. Report of the Department of Fisheries, Zambia:1-74.

Plisnier P-D (1997). Climate, limnology, and fisheries changes of Lake Tanganyika. FAO/ FINNIDA Research for the Management of the Fisheries of Lake Tanganyika. GCP/RAF/271/ FIN-TD/72 (En):38p.

Plisnier PD, Mgana H, Kimirei I, Chande A, Makasa L, Chimanga J, Zulu F, CocQuyt C, Horion S, Bergamino N, NAithani J, DELEERSNIJDER E, ANDRÉ L, DESCY JP \& CORNET Y (2009). Limnological variability and pelagic fish abundance (Stolothrissa tanganicae and Lates stappersii) in Lake Tanganyika. Hydrobiologia 625:117-134.

Poll M (1953). Poissons cichlidae, Resultats scientifiques de l'Exploration Hydrobiologique du Lac Tanganyika (1946 - 1947). Institut Royal des Sciences Naturelles de Belgique 3:251 pp.

RoEST FC (1977). Stolothrissa tanganicae, population dynamics, biomass evolution and life history in the Burundi waters of Lake Tanganyika. United Nations Food and Agriculture Organisation. CIFA Technical Paper 5:42-63.

ROEST FC (1992). The pelagic fisheries resources of Lake Tanganyika. Mitteilungen - Internationale Vereinigung für theoretische und angewandte Limnologie 23:11-15.

RUFLI H \& CHAPMAN DW (1976). Preliminary analysis of zooplankton sampling and estimates of fish abundances in Lake Tanganyika in October 1975. FI:DP/URT/71/012/31:13p.

SARVALA J, SALONEN K, JÄRVINEN M, ARO E, Huttula T, Kotilainen P, Kurki H, LANGenberg VT, MANNINI P, PELTONEN A, Plisnier PD, Vuorinen I, MÖLsä H \& LINDQVIST O (1999). Trophic structure of Lake Tanganyika:carbon flows in the pelagic food web. Hydrobiologia 407:155-179.

SaRVAla J, TARVAINEN M, SALONEN K \& MÖlsä $H$ (2002). Pelagic food web as the basis of fisheries in Lake Tanganyika:a bioenergetics modeling analysis. Aquatic Ecosystem Health \& Management 5:283-292.
SARVAla J, LANGenberG VT, SAlONEN K, Chitamwebwa D, Coulter GW, Huttula T, Kanyaru R, Kotilainen P, MaKasa L, MulimBWA N \& MÖLSÄ H (2006a). Fish catches from Lake Tanganyika mainly reflect changes in fishery practices, not climate. Verhandlungen Internationale Vereinigung für theoretische und angewandte Limnologie 29:1182-1188.

SARVAla J, LANGENBERG VT, SALONEN K, Chitamwebwa D, Coulter GW, Huttula T, Kotilainen P, Mulimbwa N \& Mölsä $\mathrm{H}$ (2006b). Changes in dissolved silica and transparency are not sufficient evidence for decreased primary productivity due to climate warming in Lake Tanganyika. Reply to comment by Verburg, Hecky and Kling. Verhandlungen Internationale Vereinigung für theoretische und angewandte Limnologie 29:2339-2342.

SHIRAKIHARA K, USE K, KAMIKAWA S \& MAMBONA WB (1992). Population changes of sardines in the northern Lake Tanganyika. African Study Monograph 13:57-67.

SNOEKS J (2000). How well known is the ichthyodiversity of the large East African lakes? Advances in Ecological Research 31:17-38.

VAN DER KNAAP M, KATONDA KI \& DE GRAAF GJ (2014). Lake Tanganyika fisheries frame survey analysis:assessment of the options for management of the fisheries of Lake Tanganyika. Aquatic Ecosystem Health \& Management 17:413.

Van Steenberge M, Vanhove MPM, Muzumani RD, Mulimbwa N, Muterezi BF, Pariselle A, Gillardin C, VReven E, RaEymaekers JAM, HuYSE T, VOLCKAERT FAM, NSHOMBO MUDERWHA V \& SNOEKS J (2011). A recent inventory of the fishes of the north-western and central western coast of Lake Tanganyika (Democratic Republic Congo). Acta Ichthyologica et Piscatoria 41:201-214.

VuORinen I, Kurki H, Bosma E, Kalangali A, MÖLSÄ H \& LINDQVIST OV (1999). Vertical distribution and migration of pelagic Copepoda in Lake Tanganyika. Hydrobiologia 407:115-121.

Received: 10 January 2014

Accepted: 12 August 2014

Branch editor: Luc Brendonck 